\title{
Bio-Contamination Estimates of Mycobacterium Avium Subspecies Paratuberculosis in Fresh Cottage Cheese (Paneer) Sold in Rural, Semi-Urban and Peri-Urban Regions of South Uttar Pradesh using Multiple Diagnostic Tests
}

\section{Bjorn John Stephen ${ }^{1}$, Manju Singh ${ }^{1}$, Shoor Vir Singh ${ }^{1 *}$, Saurabh Gupta ${ }^{1}$, Kundan Kumar Chaubey $^{1}$, Sahzad ${ }^{1}$, Sujata Jayaraman ${ }^{2}$, Mukta Jain ${ }^{2}$, Jagdip Singh Sohal ${ }^{2}$, Shivalingappa Yamanappa Mukartal ${ }^{3}$, Kuldeep Dhama ${ }^{4}$}

\begin{abstract}
${ }^{1}$ Animal Health Division, Central Institute for Research on Goats, Mathura, Uttar Pradesh, India; ${ }^{2}$ AMITY Institute of Microbial Technology, AMITY University Rajasthan, Jaipur, India; ${ }^{3}$ Department of Veterinary Microbiology, Veterinary College, Hebbal, Bengaluru, India; ${ }^{4}$ Division of Pathology, Indian Veterinary Research Institute,
\end{abstract} Izatnagar, Uttar Pradesh, India.

\begin{abstract}
Paneer (fresh cottage cheese) samples collected from local dairy shops in rural (Farah), peri-urban and urban (Mathura and Agra) regions of South Uttar Pradesh were screened by six tests combinations to estimate the rate of 'bio-contamination' and 'bio-typing' of MAP (paraTB bacilli). Of 55 paneer samples screened, 54.5, 32.7, 54.5, 74.5, 50.9 and $63.6 \%$ were positive by microscopy, IS900 PCR, indigenous ELISA kit, Dot-ELISA, Latex Agglutination test and indirect Fluorescent Antibody tests, respectively. Except 2 (3.6\%), all the positive samples were detected by minimum two tests. Of the six test combinations used and compared, microscopy (AFB vs iFAT and IS900 PCR were best combinations for the detection of MAP in fresh cottage cheese (paneer) samples. High rate of bio-contamination of paneer sold by the local dairy shops was due to the use of milk supplies contaminated with high bio-load of MAP. Milk supplies were sourced from domestic livestock belonging to local rural areas, where animal health care facilities and knowledge on bio-contamination of MAP were non-existent. Therefore, in order to produce clean milk, free of MAP bacilli it is absolutely essential to control infection in the domestic livestock.
\end{abstract}

Keywords $\mid$ Mycobacterium avium subspecies paratuberculosis, Indigenous plate ELISA, Dot- ELISA, Latex agglutination test, Indirect Fluorescent antibody test

Editor | Yashpal S Malik, Indian Veterinary Research Institute, Uttar Pradesh, India.

Received | June 30, 2016; Accepted | July 03, 2016; Published | August 20, 2016

*Correspondence | Shoor Vir Singh, Microbiology Laboratory, Animal Health Division, Central Institute for Research on Goats, Makhdoom, PO-Farah, Mathura, 281122, India; Email: shoorvir_singh@rediffmail.com

Citation | Stephen BJ, Singh M, Singh SV, Gupta S, Chaubey KK, Sahzad, Jayaraman S, Jain M, Sohal JS, Mukartal SY, Dhama K (2016). 'Bio-contamination' estimates of Mycobacterium avium subspecies paratuberculosis in fresh cottage cheese (Paneer) sold in rural, semi-urban and peri-urban regions of South Uttar Pradesh using multiple diagnostic tests. Adv. Anim. Vet. Sci. 4(8): 441-448.

DOI | Http://dx.doi.org/10.14737/journal.aavs/2016/4.8.441.448

ISSN (Online) | 2307-8316; ISSN (Print) | 2309-3331

Copyright (C) 2016 Stephen et al. This is an open access article distributed under the Creative Commons Attribution License, which permits unrestricted use, distribution, and reproduction in any medium, provided the original work is properly cited.

\section{INTRODUCTION}

$\mathrm{M}$ ycobacterium avium subspecies paratuberculosis (MAP) is the cause of Johne's disease (JD): granulomatous enteritis in domestic livestock and has been associated with Crohn's disease (CD) in humans (Messelhäusser et al., 2012; Banche et al., 2015). Association of MAP with CD has been reported in the recent past and bacilli were isolated from intestines and blood of the patients (Greenstein, 2003; Feller et al., 2007; Singh et al., 2008; Mendoza et al., 2009; Rani et al., 2010; Rosenfeld and Bressler, 2010; Chiodini et al., 2012; Naser et al., 2014). High bio-load of MAP has been frequently reported from commercial dairy milk supplies (Singh et al., 2009) and milk products (Shankar et al., 2010; Raghuvanshi et al., 2010), raw milk of cows (Sharma et al., 
2008), buffaloes (Yadav et al., 2008) goats (Raghuvanshi et al., 2010), bovines (Sharma et al., 2008; Yadav et al., 2008) and other domestic livestock species (Singh et al., 2014) in India. Shedding of MAP in milk and its presence in pasteurized milk and milk products have received high attention since milk and milk products are important vehicles of transmission to humans (Corti and Stephan, 2002; Stabel et al., 2002; Stephan et al., 2002; Carvalho et al., 2009). Milk is staple diet of an Indian, therefore at 132.43 million tonnes of milk per year (FAO, 2013). India is the highest milk producer in the world. Singh et al. (2014) reported consistent increase in the bio-load of MAP infection in the domestic livestock population at every 5 yearly interval in past 28 years (1985 to 2013). In the absence of control program for JD in domestic livestock, in recent years, the bio-load of MAP has increased manifold and infected domestic livestock continue to shed MAP bacilli in their milk, which poses a serious public health hazard.

Live MAP bacilli has been reported in pasteurized milk and milk products (Shankar et al., 2010) like fresh cheese (paneer) (Donaghy et al., 2011; Raghuvanshi et al., 2013). Paneer is one of the important milk product enriched with animal fat, proteins, minerals and vitamins. In recent times there is spurt in consumption of paneer in urban, semiurban and rural areas of the country. In industrially rich countries, public health concern of MAP as food borne pathogen has increased, since MAP is not in-activated during pasteurization (D'haese et al., 2005). Health risks also result from dormant MAP bacilli or dead cells and the structural components of MAP (Malli, 2010).

In the absence of JD control programs, disease continues to infect large number of naive animals / herds. Non-availability of rapid and accurate 'Indigenous diagnostics' tests, country lacks information on the National Prevalence of JD, therefore disease lacks information on disease incidence, therefore, priority and programs for survey and control in domestic livestock (Chaubey et al., 2016). Use of multiple tests for the diagnosis has been recommended for estimating prevalence (Collins et al., 2005; Singh et al., 2014). No single test can accurately detect MAP infection in animals. Microscopy, indigenous plate ELISA (p-ELISA) and IS900 PCR have been frequently used for the diagnosis (Sharma et al., 2008; Shankar et al., 2010; Nielsen and Toft, 2014; Garg et al., 2015) and all three tests have shown high sensitivity and specificity (Stabel et al., 2002; Collins et al., 2005; Sharma et al., 2008). We recently standardized, Indigenous dot-ELISA (d-ELISA), indirect Fluorescent antibody Test (iFAT) and Latex agglutination test (LAT) for the detection of MAP in milk samples (Singh and co-workers, 2015 unpublished data) and were employed for the screening of paneer samples in this study.
Using indiginous milk-ELISA, reasonably high bio-contamination of MAP in raw milk of dairy farms has been reported in India (Singh et al., 2013; Sharma et al., 2008) and world-wide (Eisenberg et al., 2015). Information on bio-contamination of paneer prepared from pasteurized bovine (cattle and buffaloes) milk is not available. This is the maiden attempt to estimate bio-contamination of MAP in the fresh cottage cheese (paneer) made from pooled milk of cattle and buffaloes and sold in the local markets located in rural (Farah), peri-urban and urban areas (Agra and Mathura in South Uttar Pradesh), using multiple diagnostic tests (microscopy, IS900 PCR, indigenous p-ELISA and d-ELISA and newly standardized Latex agglutination test and indirect Fluorescent antibody tests).

\section{MATERIALS AND METHODS}

\section{Collection and Screening of Paneer Samples}

Paneer samples (55) made from pooled milk of cattle and buffaloes and heated to 75 to 80 degrees Celsius (for curdling) were collected from ten local dairies around $\mathrm{Fa}^{-}$ rah town in Mathura and Agra district for the screening of MAP. About 2.0 grams of paneer sample was finely grounded in $10-12 \mathrm{ml}$ of autoclaved distilled water and centrifuged at $4500 \mathrm{rpm}$ for $40 \mathrm{~min}$ at room temperature. After centrifugation, three layers (fat, whey and sediment layer) were formed and separated out in different labelled vials. Smears prepared from fat and sediment layers were subjected to Ziehl Neelsen staining and iFAT to detect bacilli. Whey collected in separate tubes was treated with $3.0 \%$ citric acid and centrifuged at $5000 \mathrm{rpm}$ for 5 minutes. Supernatant was used to detect anti-MAP lacto-antibodies in indiginous p-ELISA, d-ELISA and LAT.

\section{Acid Fast Staining for Microscopy}

Smears were prepared from fat and sediment layers, heat fixed and stained by Ziehl Neelsen (ZN) staining as per Singh et al. (2008) and examined under oil immersion $(\times 100)$ for acid-fast bacilli (AFB) indistinguishable to MAP.

\section{Indirect Fluorescent Antibody Test (IFAT)}

Fluorescent antibody test was adopted for use in milk from the protocol developed by D' Haese et al. (2005) and Chaturvedi (2016) used for tissues with some modifications. Clean slides were taken and smears were prepared from sediment layer of processed samples and allowed to air dry at room temperature followed by heat fixing. Slides were then dipped in a solution of $30.0 \% \mathrm{H}_{2} \mathrm{O}_{2}$ in $90.0 \%$ methanol (3:7 ratio) and then incubated for 10 minutes at $37^{\circ} \mathrm{C}$, followed by dipping of slides in phosphate-citrate buffer $(2.1 \%$ citric acid and $3.56 \%$ disodium hydrogen phosphate in $100 \mathrm{ml}$ triple distilled water, $\mathrm{pH}-5$ ) and were placed in microwave for heating for 30 seconds ( 15 cycles) 
with rest for 20 seconds after each cycle (total time 10 minutes). Slides were taken out from solution and then air dried at room temperature. Then primary antibody (whey) in ratio of 1:4 in serum dilution buffer (1\% BSA in PBST) was added on the slides. Slides were incubated for 1 hour at $37^{\circ} \mathrm{C}$ in BOD incubator and was followed by washing of slides in 1X PBS (3 times). Anti-species secondary antibody (FITC conjugate) was added in the ratio 1:750 in 1X PBS (pH-7.6). Slides were then incubated in dark for 1 hour at $37^{\circ} \mathrm{C}$ and followed by washing of slides 5 times in $1 \mathrm{X}$ PBS. Slides were then air dried at room temperature. Finally, slides were mounted with glycerine and covered with coverslip and then observed immediately under the fluorescent microscope. Slides positive for MAP infection exhibited green fluorescence.

\section{DNA ISOLATION}

DNA isolation from paneer was carried out as per Grant et al. (2000) with some modifications. Sediment layer was taken with the help of a sterile cotton swab and was re-suspended in $100 \mu \mathrm{l}$ of nuclease free water. Subsequently, heat shocks were given to this sample at $100^{\circ} \mathrm{C}$ for 15 minutes in thermal cycler and immediately transferred the vial in $-20^{\circ} \mathrm{C}$ for 10 minutes. Steps were repeated two times. Samples were centrifuged at $4000 \mathrm{rpm}$ for 5 minutes to separate supernatant from sediment. Directly the supernatant was used as a template for PCR as supernatant contained the DNA from lysed MAP cells.

\section{IS900 PCR}

DNA isolated from the paneer samples was subjected to specific IS900 PCR using primers used by Vary et al. (1990). Presence and yield of the specific PCR product (229bp) was considered as positive for MAP infection.

\section{Indigenous Plate ELISA (Indigenous p-ELISA)}

Milk based indigenous 'p-ELISA' kit (Singh et al., 2007) was used as standard test for screening of animals for MAP infection and was parallel test for comparative studies. The $0.1 \mu \mathrm{g}$ of antigen in $100 \mu \mathrm{l}$ of carbonate-bicarbonate buffer, ( $\mathrm{pH}$ 9.6) was added to each well of the flat bottom 96 well ELISA plate and incubated at $4{ }^{\circ} \mathrm{C}$ overnight. Plates were washed three times with PBST (PBS with $0.05 \%$ Tween 20) followed by blocking in $100 \mu \mathrm{l}$ of $3 \%$ skimmed milk in $\mathrm{PBS}$, incubated for 60 minutes at $37^{\circ} \mathrm{C}$. The plate were then washed thrice with PBST and then test samples $(100 \mu$ of 1:4 diluted whey) were added in duplicate wells and incubated for 2 hrs at $37^{\circ} \mathrm{C}$. Plates were washed three times with PBST followed by addition of $100 \mu$ of optimally diluted rabbit anti-bovine / caprine conjugate and were again incubated for 60 minutes at $37^{\circ} \mathrm{C}$. After washing of the plates five times with PBST, $100 \mu$ of the freshly prepared OPD substrate was added to the plates and were incubated till the development of colour at $37^{\circ} \mathrm{C}$. Absorbance was read at $450 \mathrm{~nm}$ in the ELISA reader (i Mark micro-plate reader, Biorad). Whey samples collected from the weak and culture positive and those collected from healthy and culture negative buffaloes and goats were used as positive and negative controls, respectively. Optical density (OD) values were transformed and expressed as sample-to-positive $(\mathrm{S} / \mathrm{P})$ ratios as per the method of Collins (2002).

\section{Analysis of OD (Absorbance) VAlues}

$$
\mathrm{S} / \mathrm{P} \text { ratio value }=\frac{(\text { Sample OD }- \text { Negative OD })}{(\text { Positive OD }- \text { Negative OD })}
$$

Sample to positive ratios and corresponding status of JD in animals was determined as per Collins (2002). As per Singh et al. (2015), sample in low positive (LP), positive $(\mathrm{P})$ and strong positive (SP) categories of $\mathrm{S} / \mathrm{P}$ ratio considered as positive for MAP infection in indigenous milk p-ELISA.

\section{Dot- ELISA (d-ELISA)}

The dot ELISA test was performed as per Singh et al. (2015) with minor modifications. Briefly, tips of 12 legged immune-diffusion combs (Advanced Microdevices Pvt. Ltd., Ambala, Haryana, India) fixed with nitrocellulose membrane were coated with $1 \mu \mathrm{l}(2 \mu \mathrm{g}$ of sPPA in $1 \mu \mathrm{l}$ of carbonate-bi-carbonate buffer, $\mathrm{pH}$ 9.6) of sPPA spot in middle of nitrocellulose paper and incubated for 2 hours at $37^{\circ} \mathrm{C}$. Combs were dipped in blocking solution $(3.0 \%$ skimmed milk powder in PBS) for 60 minutes at $37^{\circ} \mathrm{C}$. After further washing with PBST, combs were dipped in test samples $(200 \mu \mathrm{l}$ clear whey in 1:4 dilution in $1 \% \mathrm{BSA}$ in PBS) for 60 minutes followed by washing again and then the combs were incubated with $200 \mu \mathrm{l}$ of rabbit anti-bovine and/or caprine HRP conjugate solution at $37^{\circ} \mathrm{C}$ for $30 \mathrm{~min}$. Finally, the combs were dipped in $200 \mu \mathrm{l}$ of 3 , 3'-Diaminobenzidine (6mg / $10 \mathrm{ml}$ of $1 \mathrm{X}$ PBS), at room temperature till the development of colour (1-3 min). Once the spot was visible the combs were dipped in water to stop the reaction. Positive and negative controls used in this study were confirmed by IS900 PCR and microscopy and were used on two legs of each comb to facilitate in the reading of test samples.

\section{Latex Agglutination Test}

\section{Preparation of MAP Antigen Coated Latex Beads:} $10 \mu 1$ of polystyrene latex beads $(3.0 \mu \mathrm{m}$ mean size, Sigma Aldrich) were washed four times with distilled water and re-suspended in $20 \mu \mathrm{l}$ of $0.5 \mathrm{M}$ glycine saline buffer $(\mathrm{pH}-$ 8.6) to which $20 \mu \mathrm{l}$ of antigen $(0.4 \mu \mathrm{g} / \mathrm{ml})$ was added and incubated for 3 hours at $37^{\circ} \mathrm{C}$ in shaker incubator. Mixture was then centrifuged at $5000 \mathrm{rpm}$ for 10 minutes and after aspirating the supernatant, the mixture was re-suspended in a blocking solution ( $3 \%$ skimmed milk powder in PBS) 
Table 1: Screening of paneer samples from rural, semi-urban and peri-urban regions of South Uttar Pradesh for the presence of Mycobacterium avium subspecies paratuberculosis infection using multiple tests

\begin{tabular}{llllllll}
\multicolumn{1}{c}{ Milk samples } & Microscopy & & IS900 PCR & p-ELISA & d-ELISA & LAT & iFAT \\
& Fat & Sediment & Sediment & Whey & Whey & Whey & Sediment \\
55 & $09(16.3)$ & $21(38.1)$ & $18(32.7)$ & $30(54.5)$ & $41(74.5)$ & $28(50.9)$ & $35(63.6)$
\end{tabular}

*Figures in parenthesis are percent

Table 2: Comparative detection of Mycobacterium avium subspecies paratuberculosis in paneer $(\mathrm{n}=55)$ made from bovines milk (buffaloes and cattle) using six tests

\begin{tabular}{|c|c|c|c|c|c|c|c|c|c|c|c|c|c|c|c|}
\hline \multirow{2}{*}{$\begin{array}{l}\text { Diagnostic } \\
\text { tests }\end{array}$} & \multicolumn{14}{|c|}{ Combinations } & \multirow[t]{2}{*}{ Total } \\
\hline & 1 & 2 & 3 & 4 & 5 & 6 & 7 & 8 & 9 & 10 & 11 & 12 & 13 & 14 & \\
\hline p-ELISA & + & - & + & + & - & - & + & + & - & + & - & + & - & + & 30 \\
\hline d-ELISA & + & - & + & + & + & + & + & + & + & + & + & + & + & + & 41 \\
\hline LAT & + & - & + & - & + & + & + & + & - & - & + & - & - & - & 28 \\
\hline Microscopy* & + & - & + & + & + & + & - & - & - & - & - & + & + & - & 30 \\
\hline iFAT & + & - & + & + & + & + & + & - & - & - & - & + & + & + & 35 \\
\hline IS900 PCR & + & - & - & + & + & - & - & - & - & - & - & - & + & - & 18 \\
\hline Total & 8 & 14 & 6 & 6 & 3 & 4 & 4 & 2 & 2 & 1 & 1 & 2 & 1 & 1 & \\
\hline
\end{tabular}

*: Both fat and sediment; Total samples: 55

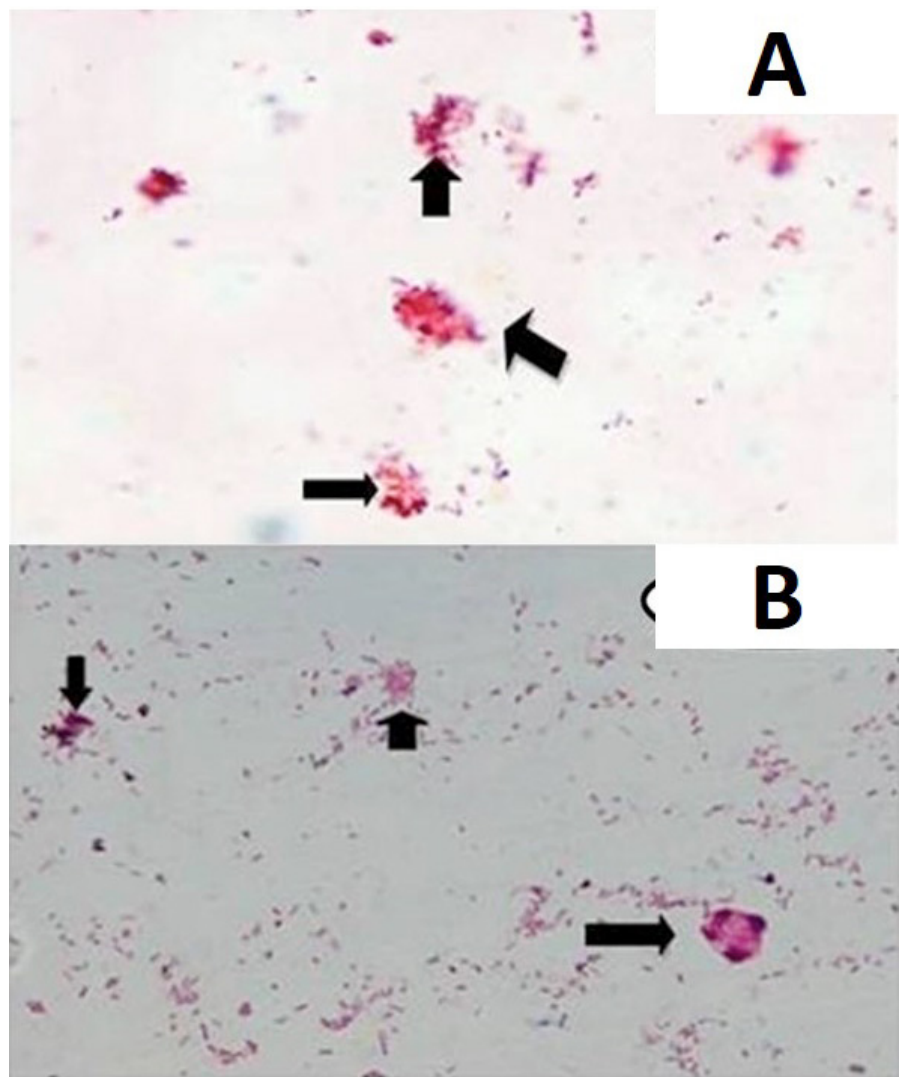

Figure 1: MAP bacilli as seen in acid fast staining in paneer samples

and mixed for an additional $45 \mathrm{~min}$ at $37^{\circ} \mathrm{C}$. Finally, the beads were washed two times in 1XPBST.

Test Proper: Latex agglutination assay was performed by placing $4 \mathrm{ul}$ of whey samples on a glass slide. Subsequently, the milk drops were mixed with $2 \mu \mathrm{l}$ of conjugated latex beads. Latex and milk samples were mixed with the disposable tip of a pipette. Slide was then gently shaken for 2 min. The test samples were considered as positive for MAP infection, if agglutination was observed within 2 minutes. Samples were taken as negative if agglutination was not observed within 2 minutes time, the samples were taken as negative.

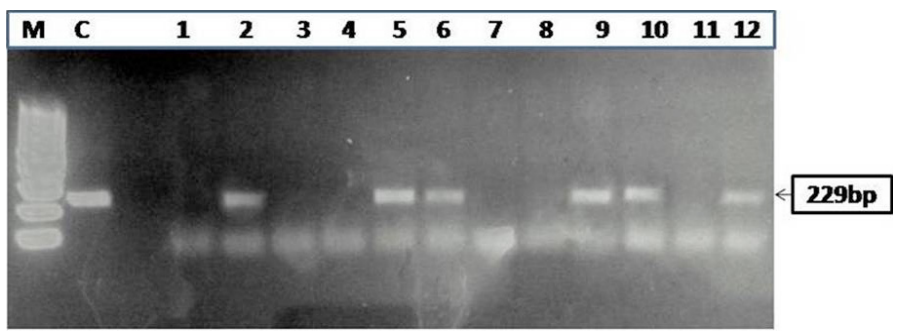

Figure 2: Agarose gel electrophoresis of $\mathrm{PCR}$ products obtained by IS900 PCR performed on paneer $(n=55)$ samples

\section{Statistical Analysis}

To measure significance between the two tests analysed statistically. Mc Nemar's test and kappa agreement statistical analysis methods have been applied by Graph Pad software, USA.

\section{RESULTS}

Of 55 paneer samples (fat and sediment layers) screened, 54.5\% (30), 32.7\% (18), 54.5\% (30), 74.5\% (41), 50.9\% (28) 
Table 3: Comparative analysis of paneer samples $(n=55)$ between Mc-Nemar test and Kappa agreement

\begin{tabular}{lllll} 
Tests & P-value & Kappa & Strength of agreement & 95\% Confidence interval \\
\hline p-ELISA vs d-ELISA & 0.0026 & 0.581 & Moderate & 0.380 to 0.782 \\
p-ELISA vs LAT & 0.8137 & 0.344 & Fair & 0.097 to 0.592 \\
d-ELISA vs LAT & 0.0005 & 0.523 & Moderate & 0.324 to 0.722 \\
\hline AFB* vs $i$ FAT $^{\text {AFB* } \text { v IS900 PCR }}$ & 0.0736 & 0.814 & Good & 0.660 to 0.967 \\
iFAT vs IS900 PCR & 0.0133 & 0.704 & Good & 0.522 to 0.885 \\
\hline
\end{tabular}

*AFB or Microscopy

and 63.6\% (35) were positive for MAP infection in microscopy (Figure 1A and 1B), IS900 PCR (Figure 2), indigenous p-ELISA, d-ELISA (Figure 3), Latex agglutination test (Figure 4) and iFAT (Figure 5), respectively (Table 1). Of total paneer samples screened in $40.0 \%$ samples there was perfect agreement in all the 6 tests $[14.5 \%$ positive and $25.4 \%$ negative). In remaining 41 samples, except 2 (3.6\%) samples, which were positive only in dot-ELISA, rest 31 (56.3\%) samples were positive in more than one test (two or five) performed (Table 1 and 2). Cumulatively, of 55 samples screened $38(69.0 \%)$ were positive in more than one test and may be considered as true positives and $25.4 \%$ (14) as true negatives (negatives in 6 tests).

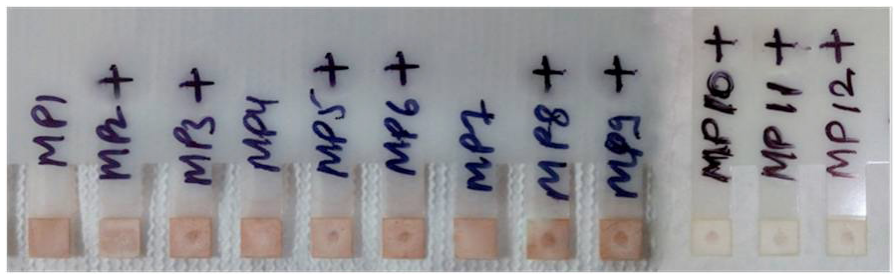

Figure 3: Dot-ELISA of paneer $(\mathrm{n}=55)$ samples showing brown dot for the samples positive for MAP
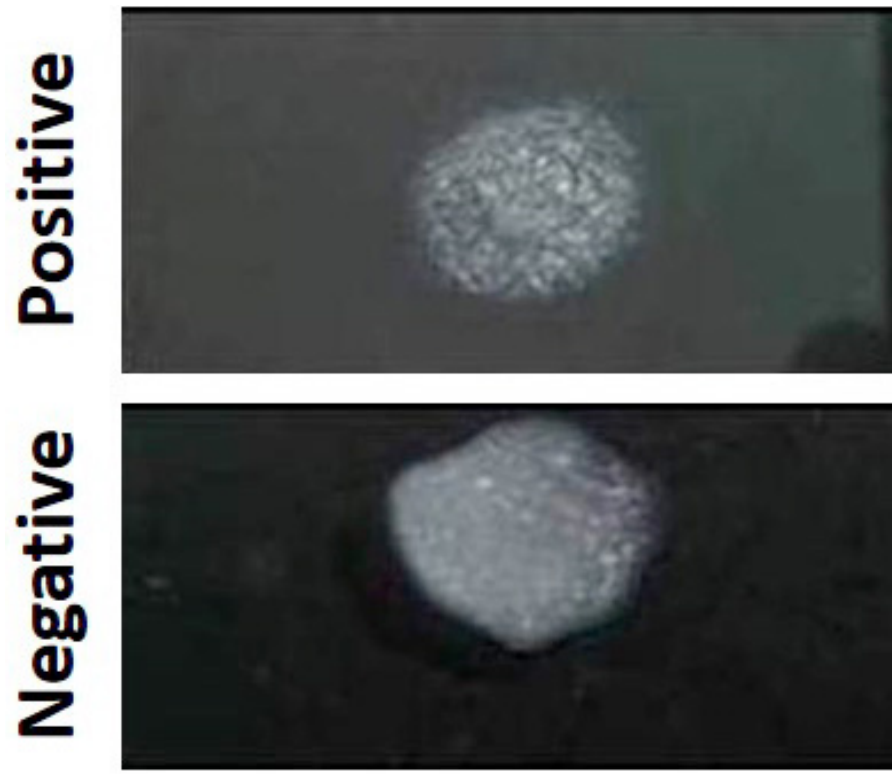

Figure 4: The presence and absence of agglutination in MAP positive and negative samples as observed by Latex Agglutination test
Therefore, out of 55 samples, 96.3\% (53) were correctly identified by more than one test of the six diagnostic tests used and only 3.6\% (2) samples detected by d_ELISA alone can be considered as false positives or doubtful. Of the six tests used dot ELISA was most sensitive followed by iFAT, Microscopy, indigenous p_ELISA, LAT and IS900 PCR, respectively. Comparisons between tests were evaluated statistically with $\mathrm{p}$-Value was found to be 'significantly different'. Strength of agreement was estimated to be 'Good' for microscopy (AFB) with respect to FAT and IS900 PCR and had kappa value of 0.814 and 0.704 , respectively. Strength of agreement was estimated to be 'moderate' for indigenous $\mathrm{p}$-ELISA with respect to $\mathrm{d}$-ELISA. D-ELISA vs LAT and iFAT vs IS900 PCR had kappa value of $0.581,0.523$ and 0.435 , respectively.

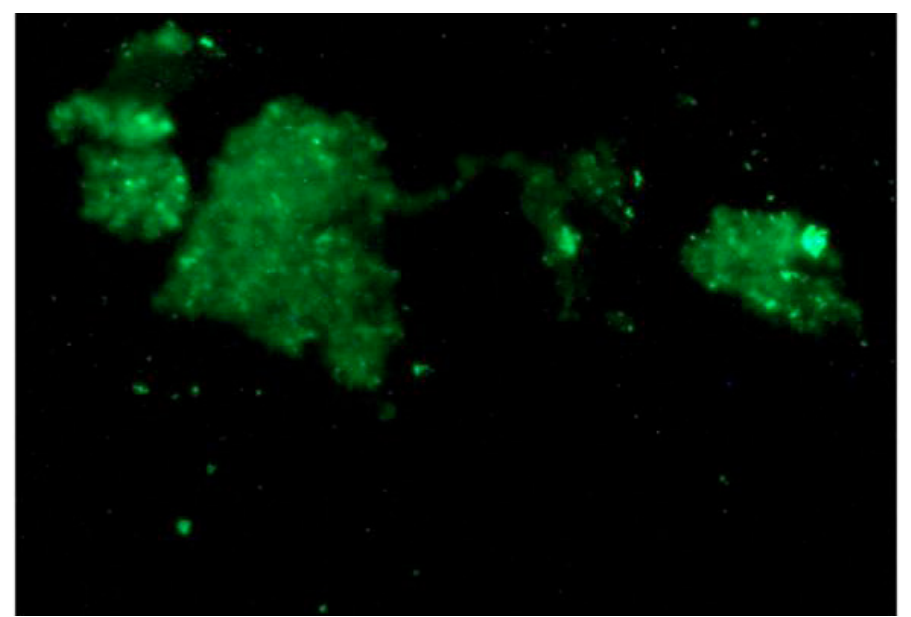

Figure 5: Green fluorescence indicating the presence of MAP bacilli in paneer samples by Indirect Fluorescent antibody test (iFAT)

\section{DISCUSSION}

Johne's disease is progressive and chronic enteritis, caused by the infection of Mycobacterium avium subspecies paratuberculosis (MAP) in domestic ruminants world-wide. Bio-contamination of pasteurized milk and milk products with live MAP bacilli has been frequently reported worldwide. Information is extremely limited on the bio-contamination of milk products in India, though MAP has been found to be endemic in the livestock population of the 
country (Singh et al., 2014), therefore MAP is the major threat to public health and food safety in these countries. Paneer or fresh cheese is the most important milk product used in one meal per day in urban areas. Consumption of contaminated milk and milk products could lead to Crohn's Disease, a systemic enteritis associated with MAP infection in human beings. Using milk ELISA, reasonably high bio-contamination of MAP has been reported in the raw milk of dairy farms in India (Singh et al., 2013; Sharma et al., 2008) and around world (Eisenberg et al., 2015). Little information exists on the bio-contamination of MAP in paneer prepared from pasteurized bovine (cattle and buffaloes) milk. Present study is the maiden attempt to estimate bio-contamination of MAP in the samples of paneer made in rural (Farah), peri-urban and urban areas (Agra and Mathura) from pooled milk of cattle and buffaloes in South Uttar Pradesh, using multiple tests (microscopy, IS900 PCR, indigenous p-ELISA and d-ELISA and newly standardized Latex agglutination test and indirect Fluorescent antibody tests).

In 2014, Singh and co-workers reported bio-load of MAP between $7.6-69.8 \%$ and $23.0-84.4 \%$ in goats and cattle milk, respectively using 'Indigenous milk-ELISA' and 'IS900 PCR. Also the bio-presence of MAP was 43.7 and $72.2 \%$ using milk culture and 6.2 and $38.8 \%$ using IS900 PCR in unpasteurized and pasteurized milk. In another study, 65 milk samples were screened wherein, 20 (30.7\%), 9 (13.8\%) and $5(7.6 \%)$ were found positive for MAP infection by indigenous $\mathrm{p}$-ELISA, microscopy and IS900 PCR, respectively. Of 48 individual goat milk samples screened, MAP positivity was highest in indigenous p-ELISA (37.5\%) followed by microscopy (16.6\%) and IS900 PCR (8.3\%) as compared to pooled milk samples where positivity was $11.7 \%, 5.8 \%$ and $5.8 \%$, in indigenous p-ELISA, microscopy and IS900 PCR respectively ( $\mathrm{Ra}^{-}$ ghuvanshi et al., 2010). Raghuvanshi et al. (2010) screened 24 paneer samples made from the milk of goats endemic for Johne's disease and found, 4 (16.6\%) and 0 (0\%) were positive in microscopy and IS900 PCR, respectively and of the 4 positive samples, $3(12.5 \%)$ and 1 (4.2\%) were positive in fat and sediment fractions of paneer, respectively (Raghuvanshi et al., 2013). Sharma et al. (2008) reported higher recovery of MAP in sediment layer as compared to fat in the milk of cattle. We observed similar results during microscopy, where fewer bacilli were observed in fat layers as compared to the sediment. Of 55 samples, 09 (16.3\%) and 21 (38.1\%) were positive in microscopy in the fat and sediment fractions of paneer samples, respectively. Low rate of infection in paneer samples from CIRG goats was due to regular screening and culling of JD positive goats. And high positivity in sediment layer of goat milk was due to low fat contents, thus MAP bacilli getting partitioned with sediment layer.
Globally MAP has been most frequently reported from the milk products made from cow's milk (Sechi and Dow, 2015; Grant, 2003). Due to high bio-prevalence of MAP infection in the domestic livestock of the country, therefore it was a great concern to know about the status of MAP infection in the paneer samples bought from the local stores of the region. Though paneer is prepared from pasteurized milk, due to their waxy cell wall and clumping MAP bacilli survive pasteurization. Published reports proved the existence of MAP in non-pasteurized and pasteurized milk, colostrums, milk powder and all types of fresh cheese (Ayele et al., 2005; Bradner et al., 2013). In this study, $41(74.5 \%)$ of the paneer samples were positive in either one or more tests, while $8(14.5 \%)$ were positive in all test. Of the 6 tests, $41(74.5 \%)$ and $30(54.5 \%)$ were positive in d-ELISA and indigenous p-ELISA respectively. The high percent positivity in d-ELISA was also observed in our previous reports which showed a relatively high number of false positives when compared with indigenous p-ELISA. However, LAT, which is also antibody detection test, showed 28 (50.4\%) samples positive for MAP infection. In the antigen detection tests, IS900 PCR, iFAT and microscopy, the total number of positive results for MAP infection were 18 (32.7\%), 30 (54.5\%) and 35 (63.6\%), respectively. These data suggests high bio-contamination of MAP in paneer samples which could be due to production of paneer from the milk of JD infected animals. Killing of the bacilli requires high temperature like boiling and hence we strongly recommend that paneer should be properly cooked before consumption. This is the first study to record the high bio-contamination of MAP in the paneer (fresh cheese) sold in the local market. Further, large scale sampling would be required to provide real time estimates of the MAP bio-contamination of milk products sold by local dairies in South Uttar Pradesh in North India.

\section{CONCLUSION}

This study is first to report high 'bio-contamination' of paneer (fresh cottage cheese) samples collected from local dairies, where it was prepared from pasteurized pooled milk of cattle and buffaloes. Multiple tests were useful in confirming the 'bio-contamination' of paneer samples. Milk used in these local dairies was from animals infected with JD (Singh et al., 2013). Milk and milk products made for human consumption may preferably be prepared from boiled milk so as to prevent the transmission of MAP from animals to human population.

\section{ACKNOWLEDGMENTS}

Authors are thankful to Ministry of Food Processing Industries (MOFPI) for the financial grant (SERB/MOFPI/ EC?0029/2014) and Science and Engineering Research 
OPEN OACCESS

Board (SERB) and Department of Science and Technology (DST), Government of India, for monitoring the project. Authors are also thankful to the Director, CIRG, Makhdoom for providing necessary facilities.

\section{CONFLICT OF INTERESTS}

No Conflict of Interest to declare.

\section{AUTHORS' CONTRIBUTION}

Stephen BJ was JRF in the project, Jain, M, (JRF) and Dr J.S. Sohal, Assistant Professor, were involved in the standardization of Nano Immuno Rapid test. M. Chaudhary was JRF in the project, other RAs (S.Gupta and K.K.Chaubey) and Sahzad (JRF) and Dr S.V. Singh (Principal Scientist and Head) were involved in standardization and validation of dot-ELISA, validation of indigenous p-ELISA, and indigenous iFAT, microscopy, IS900 PCR and LAT tests on paneer samples. S.Y. Mukartal underwent training during this period and participated in the above mentioned work. Dr K. Dhama did the proof reading of the manuscript.

\section{REFERENCES}

-Ayele WY, Svastova P, Roubal P, Bartos M, Pavlik I (2005). Mycobacterium avium subspecies paratuberculosis Cultured from Locally and Commercially Pasteurized Cow's Milk in the Czech Republic. Appl. Environ. Microbiol. 71: 210-1214. http://dx.doi.org/10.1128/AEM.71.3.12101214.2005

-Banche G, Allizond V, Sostegni R, Lavagna A, Bergallo M, Sidoti F, Daperno M, Rocca R, Cuffini AM (2015). Application of multiple laboratory tests for Mycobacterium avium ssp. paratuberculosis detection in Crohn's disease patient specimens. New Microbiol. 38: 357-367.

-Bradner-Laura K, Stabel, Judith R, Beitz-Donald C, Suelee RA (2013). Shedding of Mycobacterium avium subsp. paratuberculosis into milk and colostrum of naturally infected dairy cows over complete lactation cycles. Animal Industry. Report: AS 659: ASL R2793.

-Carvalho IA, Silva A, Campos VE, Moreira MA (2009). Short communication: Detection of Mycobacterium avium subspecies paratuberculosis by polymerase chain reaction in bovine milk in Brazil. J. Dairy Sci. 92: 5408-10. http:// dx.doi.org/10.3168/jds.2008-1816

- Chaubey KK, Gupta RD, Gupta S, Singh SV, Bhatia AK, Jayaraman S, Kumar N, Goel A, Rathore AS, Sohal JS, Stephen BJ, Singh M, Goyal M, Dhama K, Derakhshandeh A (2016). Trends and advances in the diagnosis and control of paratuberculosis in domestic livestock. Vet Quarterly. 29:125. http://dx.doi.org/10.1080/01652176.2016.1196508

-Chiodini RJ, Chamberlin WM, Sarosiek J, McCallum RW (2012). Crohn's disease and the mycobacterioses: a quarter century later. Causation or simple association?. Crit. Rev. Microbiol. 38: 52-93. http://dx.doi.org/10.3109/104084 1X.2011.638273

-Collins MT, Wells SJ, Petrini KR, Collins JE, Schultz RD, Whitlock RH (2005). Evaluation of five antibody detection tests for diagnosis of bovine paratuberculosis. Clin. Diagn. Lab. Immunol. 12: 685-692. http://dx.doi.org/10.1128/ cdli.12.6.685-692.2005

- Collins MT (2002). Interpretation of a commercial bovine paratuberculosis enzyme-linked immunosorbent assay by using likelihood ratios. Clin. Diagn. Lab. Immunol. 9: 1367.

-Corti S and Stephan R (2002). Detection of Mycobactrium avium subsp. paratuberculosis specific IS900 insertion sequences in bulk-tank milk samples obtained from different regions throughout Switzerland. BMC Microbiol. 2: 15. http:// dx.doi.org/10.1186/1471-2180-2-15

-Chaturvedi S, Singh SV, Srivastava AK, Gangwar NK, Kumar N, Rawat KD, Gupta S, Chaubey KK, Singh R, Singh R, Dhama K (2016). Comparative evaluation of FAT, IS 900 PCR and microscopy vis a vis histo-pathology for the detection of Mycobacterium avium subsp paratuberculosis infection in tissues of goats naturally died in herds endemic for Johne's disease. Indian J. Anim. Sci. (In Press).

-D'Haese-Dumon I, Werbrouck H, De Jonghe V, Herman L (2005).Improved detection of Mycobacterium paratuberculosis in milk. J. Dairy Res. 72: 1-4.

-Donaghy JA, Johnston J, Rowe MT (2011). Detection of Mycobacterium avium ssp. paratuberculosis in cheese, milk powder and milk using IS900 and f57-based qPCR assays. J. Appl. Microbiol. 110: 479-89. http://dx.doi.org/10.1111/ j.1365-2672.2010.04905.x

-Eisenberg SW, Veldman E, Rutten VP, Koets AP (2015). A longitudinal study of factors influencing the result of a Mycobacterium avium ssp. paratuberculosis antibody ELISA in milk of dairy cows. J. Dairy Sci. 98: 2345-55. http:// dx.doi.org/10.3168/jds.2014-8380

-FAO (2013). Food and Agriculture Organization of the United Nations. http://faostat3.fao.org/home

-FAO (2015). Food and Agriculture Organization of the United Nations. http://faostat3.fao.org/home

- Feller M, Huwiler K, Stephan R, Altpeter E, Shang A, Furrer H, Pfyffer GE, Jemmi T, Baumgartner A, Egger M (2007). Mycobacterium avium subspecies paratuberculosis and Crohn's disease: A systematic review and meta-analysis. Lancet Infect. Dis. 7: 607-13.

- Garg R, Patil PK, Singh SV, Sharma S, Gandham RK, Singh AV, Filia G, Singh PK, Jayaraman S, Gupta S, Chaubey KK, Tiwari R, Saminathan M, Dhama K, Sohal JS (2015). Comparative evaluation of different test combinations for diagnosis of Mycobacterium avium subspecies paratuberculosis infecting dairy herds in India. Bio. Med. Res. Int. 2015: 983978. http://dx.doi.org/10.1155/2015/983978

- Grant IR (2003). Mycobacterium paratuberculosis and milk. Acta. Vet. Scand. 44: 261-6.

-Grant IR, Popea CM, O'Riordana LM, Ballb HJ, Rowea MT (2000). Improved detection of Mycobacterium avium subsp. paratuberculosis in milk by immunomagnetic PCR. Vet. Microbiol. 77: 369-378. http://dx.doi.org/10.1016/S0378$1135(00) 00322-9$

-Greenstein RJ (2003). Is Crohn's disease caused by a Mycobacterium? Comparisons with leprosy, tuberculosis, and Johne's disease. Lancet Infect. Dis. 3: 507-14. http:// dx.doi.org/10.1016/S1473-3099(03)00724-2

-Leonardo, Sechi A, Dow CT (2015). Mycobacterium avium ssp. paratuberculosis Zoonosis - The Hundred Year War - Beyond Crohn's Disease. Front Immunol. 6: 96.

-Malli ZD (2010). Detection of Mycobacterium avium subsp. paratuberculosis in milk from clinically affected sheep and 
goats. Int. J. Appl. Res. Vet. Mad. 8: 44.

-Mendoza JL, Lana R, Diaz-Rubio M (2009). Mycobacterium avium subspecies paratuberculosis and its relationship with Crohn's disease. World J. Gastroenterol. 15: 417-22. http:// dx.doi.org/10.3748/wjg.15.417

- Messelhäusser U, Kämpf P, Hörmansdorfer S, Wagner B, Schalch B, Busch U, Höller C, Wallner P, Barth G, Rampp A (2012). Culture and molecular method for detection of Mycobacterium tuberculosis complex and Mycobacterium avium subsp. paratuberculosis in milk and dairy products. Appl. Environ. Microbiol. 78: 295-7. http://dx.doi. org/10.1128/AEM.06322-11

- Naser SA, Sagramsingh SR, Naser AS, Thanigachalam S (2014). Mycobacterium avium subspecies paratuberculosis causes Crohn's disease in some inflammatory bowel disease patients. World J. Gastroenterol. 20: 7403-15. http://dx.doi. org/10.3748/wjg.v20.i23.7403

- Nielsen SS and Toft N (2014). Bulk tank milk ELISA for detection of antibodies to Mycobacterium avium subsp. paratuberculosis: Correlation between repeated tests and within-herd antibody-prevalence. Prev. Vet. Med. 113: 96102. http://dx.doi.org/10.1016/j.prevetmed.2013.10.013

- Raghuvanshi TS, Sharma RB, Singh AV, Singh B, Singh SV, Dhama K (2010). 'Indigenous milk ELISA kit' vis a vis multiple test regime for the estimation of lacto-prevalence of Mycobacterium avium subspecies paratuberculosis in goatherds endemic for Johne's disease. Indian J. Comp. Microbiol. Immunol. Infect. Dis. 31: 41-43.

- Raghuvanshi T, Singh S, Sharma RB, Gupta S, Chaubey KK, Kumar N, Dhama K (2013). Identification of Mycobacterium Avium Subspecies paratuberculosis in Fresh Cheese (Paneer) from Goat Herds Endemic for Johne's disease. J. Inf. Mol. Biol. 1: 46-48.

-Rani PS, Sechi LA, Ahmed N (2010). Mycobacterium avium subsp. paratuberculosis as a trigger of type-1 diabetes: Destination Sardinia, or beyond? Gut. Pathog. 2: 1. http:// dx.doi.org/10.1186/1757-4749-2-1

- Rosenfeld G and Bressler B (2010). Mycobacterium avium paratuberculosis and the etiology of Crohn's disease: A review of the controversy from the clinician's perspective. Can. J. Gastroenterol. 24: 619-24. http://dx.doi. org/10.1155/2010/698362

- Shankar H, Singh SV, Singh PK, Singh AV, Sohal JS, Greenstein RJ (2010). Presence, characterization, and genotype profiles of Mycobacterium avium subspecies paratuberculosis from unpasteurized individual and pooled milk, commercial pasteurized milk, and milk products in India by culture, PCR, and PCR-REA methods. Int. J. Infect. Dis. 14: 121126. http://dx.doi.org/10.1016/j.ijid.2009.03.031

- Sharma G, Singh SV, Sevilla I, Singh AV, Whittington RJ, Juste RA, Kumar S, Gupta VK, Singh PK, Sohal JS, Vihan VS (2008). Evaluation of indigenous milk ELISA with $\mathrm{m}$-culture and $\mathrm{m}$-PCR for the diagnosis of bovine Johne's disease (BJD) in lactating Indian dairy cattle. Res. Vet. Sci. 84: 30-7. http://dx.doi.org/10.1016/j.rvsc.2007.03.014

- Singh SV, Singh AV, Singh R, Sandhu KS, Singh PK, Sohal JS, Gupta VK, Vihan VS (2007). Evaluation of highly sensitive indigenous milk ELISA kit with fecal culture, milk culture and fecal-PCR for the diagnosis of bovine Johne's disease (BJD) in India. Comp. Immunol. Microbiol. Infect. Dis. 30: 175-86. http://dx.doi.org/10.1016/j.cimid.2006.12.002

-Singh AV, Singh SV, Makharia GK, Singh PK, Sohal JS (2008). Presence and characterization of Mycobacterium avium subspecies paratuberculosis from clinical and suspected cases of Crohn's disease and in the healthy human population in India. Int. J. Infect. Dis. 12: 190-197. http://dx.doi. org/10.1016/j.ijid.2007.06.008

- Singh AV, Chauhan DS, Singh A, Singh PK, Sohal JS, Singh SV (2015). Application of IS1311 locus 2 PCR REA assay for the specific detection of 'Bison type' Mycobacterium avium subspecies paratuberculosis isolates of Indian origin. Indian J. Med. Res. 141: 55-61. http://dx.doi.org/10.4103/09715916.154497

- Singh SV, Sohal JS, Kumar N, Gupta S, Chaubey KK, Rawat KD, Chakraborty S, Tiwari R, Dhama K (2014). Recent approaches in diagnosis and control of Mycobacterial infections with special reference to Mycobacterium avium subspecies paratuberculosis. Adv. Anim. Vet. Sci. 2: 1-11. http://dx.doi.org/10.14737/journal.aavs/2014/2.1s.1.12

-Singh SV, Sohal JS, Singh PK, Singh AV (2009). Genotype profiles of Mycobacterium avium subspecies paratuberculosis isolates recovered from animals, commercial milk, and human beings in North India. Int. J. Infect. Dis. 13: 221-7. http://dx.doi.org/10.1016/j.ijid.2008.11.022

- Singh SV, Singh AV, Singh R, Sandhu KS, Singh PK, Sohal JS, Gupta VK, Vihan VS (2007). Evaluation of highly sensitive indigenous milk ELISA kit with fecal culture, milk culture and fecal-PCR for the diagnosis of bovine Johne's disease (BJD) in India. Comp. Immunol. Microbiol. Infect. Dis. 30: 175-86. http://dx.doi.org/10.1016/j.cimid.2006.12.002

- Singh SV, Kumar N, Chaubey KK, Gupta S, Rawat KD (2013). Bio-presence of Mycobacterium avium subspecies paratuberculosis infection in Indian livestock farms. Res. Opin. Anim. Vet. Sci. 3: 401-106.

-Stabel JR, Wells SJ, Wagner BA (2002). Relationships between fecal culture, ELISA, and bulk tank milk test results for Johne's disease in US dairy herds. J. Dairy Sci. 85: 525-531. http://dx.doi.org/10.3168/jds.S0022-0302(02)74104-0

-Sechi LA, Dow CT (2015). Mycobacterium avium ss. paratuberculosis Zoonosis - The Hundred Year War-Beyond Crohn's Disease. Front. Immunol. 6: 96.

-Stephan R, Bühler K, Corti S (2002). Incidence of Mycobacterium avium subspecies paratuberculosis in bulk-tank milk samples from different regions in Switzerland. Vet. Rec. 150: 214-5. http://dx.doi.org/10.1136/vr.150.7.214

- Vary PH, Andersen PR, Green E, Hermon-Taylor J, McFadden JJ (1990). Use of highly specific DNA probes and the polymerase chain reaction to detect Mycobacterium paratuberculosis in Johne's disease. J. Clin. Microbiol. 28: 933-937.

-Yadav D, Singh SV, Singh AV, Sevilla I, Juste RA, Singh PK, Sohal JS (2008). Pathogenic 'Bison-type' Mycobacterium avium subspecies paratuberculosis genotype characterized from riverine buffalo (Bubalus bubalis) in North India. Comp. Immunol. Microbiol. Infect. Dis. 31: 373-387. http://dx.doi. org/10.1016/j.cimid.2007.06.007 